\title{
Portraits of a Mature God: Choices in Old Testament Theology
}

\author{
Mark McEntire \\ Minneapolis: Fortress Press 2013 \\ Pages: 251 \\ ISBN 978-0-8006-9941-3
}

\author{
Reviewed by Jonathan Huggins \\ Research Associate in the Theology Faculty \\ Stellenbosch University
}

7 his impressive and innovative work outlines an emerging approach to the discipline of Old Testament theology. It is an effort to examine the narrative character development of God within the story that the Old Testament tells. The author regards the Old Testament "as a narrative in which the divine character is being developed through a portrayal of the character's actions" (46). Taking a more or less canonical approach to this development, it is the "God at the end of the story" that is most developed. This approach allows a reader to move away from (though not entirely) earlier portrayals of God in favour of newer ones that emerge later in Jewish history.

McEntire's book tends to focus more on what is developing, or changing, in the divine character than on what is consistent or continuous. For him, there is no univocal presentation of God in the biblical storyline. Additionally, as God's character develops, God also begins to disappear from the story. God is a 'receding' character that "moves toward hiddenness and ambiguity as the story progresses" (11). But the God character portrayed at the end of the story is 'clearly more mature' (14), as opposed to the 'more interesting' (14) portrayal of God at the beginning of the story. This does not mean that God is actually going through some maturation process in God's own being. McEntire regards suggestion as an untestable error. He also doesn't want to suggest that the people's understanding of God is all that develops - from primitive to more sophisticated. He simply wishes to note how God behaves differently in different parts of the story. The final/canonical literary shape of the Bible's story reflects the later periods of Jewish history in which the people remember their ancestors' experience of God and contrast that with their own.

McEntire argues that later characters and writers of the biblical story remember God's actions in the past in a way that conflicts with their own 'narrative present' experience of God. They may look back for encouragement, but their present is often full of emptiness of God's absence. Thus, the question is raised whether or not God is really changing in some way as the narrative continues. Does God recede into the background? Is God replaced by other means of authoritative communication (such as prophets, or the scriptural writings)? McEntire aims to show that describing God as a developing character is a valid approach to doing Old Testament theology.

Throughout the book McEntire interacts with many important figures and works in Old Testament theology. He crafts his own contribution by progressing through the biblical narrative and arguing for particular understandings of God at various points. So he begins with the 'creative and energetic God' of the earliest parts of the canon, namely Genesis 111. This portrait of God is mysterious and difficult to understand. Genesis 12 - 
Deuteronomy 34 portrays a 'commanding and delivering God' who is 'difficult to resist' (51) because he is active in providing the people with what they need. However, the human characters become more highly developed in this section of the story, and the divine character begins to appear more absent. Next we encounter the 'nation-building God,' beginning with the book of Joshua and continuing into the books of Kings and Chronicles, in which "God has become an active speaking character in the narrative again" (95). After this period of Israelite history we encounter 'a punishing and destroying God.' McEntire notes that it is difficult to state precisely when the story of Israel begins to deteriorate, he chooses the more traditional point of the division of the kingdoms into north (Israel) and South (Judah) because it is a concrete moment in that chapter of Israel's story. This section also sees the rise in prominence of the prophets (and their writings) who present portraits of God in response to many crises.

The last section of the book focuses on the divine character as a 'restoring God.' The argument centers upon the books of Ezra-Nehemiah, though reference is also made to Daniel, Esther, Ruth, Job, Proverbs and some Psalms. The entire book has been working towards this chapter. McEntire regards the divine character portrayed here at the end of the story to be the expression of God that should be given the prominent place in the practice of Old Testament theology. He believes that this picture of God is "the one most consistent with the religious experience of those who shaped (the final form of the Hebrew Scriptures)" (175). In this part of the narrative present, God's active ways seem 'severely diminished,' and God acts more in 'vague and indirect ways.' Most of God's work takes place 'inside of human beings,' and often the human being is a foreign king! The older characterizations of God are not forgotten, but the people in the narrative present are experiencing a different sort of divine being. Thus, the "end of the story... is very different from its beginning, particularly in the way it portrays the divine character" (205). For McEntire, this is the 'mature' portrait. But I think a better word must be chosen if he wishes to encourage a wider reading of his work. Perhaps, a 'developed' portrait of God that corresponds with human experience at the end of the Old Testament narrative is a better way to speak of this. By using the word 'mature,' McEntire cannot entirely escape the previously noted error of assuming a maturation process in the divine being.

For the most part, McEntire regards the various portrayals of God throughout the biblical narrative as difficult and/or problematic. He emphasizes mainly the discontinuous aspects of the divine character. At the end of the story God is a very complex character who seems to create tension for the narrative characters and their readers. They cannot forget the God of the past, but struggle to understand how that God relates to their narrative present. This God is met with varying degrees of satisfaction by those at the story's end. But McEntire assures us that "they also make significant progress toward developing a divine character who can accompany the human narrative characters and potential readers in that movement [into a different and more complex world than their ancestors']” (209). Just the same, the unfortunate result of this study is that one comes away with a rather negative impression of the divine character. The goodness and love of God are hard to find in McEntire's analysis.

At times I think McEntire reads too much into certain passages in order to justify his argument. His interpretations are sometimes more convenient than compelling. He overlooks important passages that may contradict his hypothesis. He does not take sufficient account of ancient idiom, culture, or anthropomorphic accounts of God. And he does not think it is fully appropriate to look to the New Testament for answers to Old 
Testament dilemmas. At the same time, the book is very scholarly and well written. The larger argument of the book is an important, convincing, and thought-provoking contribution to the field of Old Testament studies. McEntire wants to bring "the mature God found at the conclusion of this long narrative journey to the center of the theological discussion” (210). He makes a strong case for this proposal. However, readers may have problems with some of the details of his argument. Nonetheless, this work should be read by all who work or are interested in the field of Old Testament Theology. 